\title{
The Role of Bank-based and Market-based Financial Development on Economic Growth of Nepal
}

\author{
Surya Bahadur Rana'
}

\begin{abstract}
This study examines the empirical relationship between economic growth and various measures of stock market and banking development in Nepal over the sample period 1987/88 to 2015/16 using a framework of endogenous growth model suggested by Romer (1986), Rebelo (1991) and Pagano (1993). The study finds that stock market size, liquidity and banking development measures predict the economic growth in the context of Nepal. Similalry, the study results show the important role of banking development on economic growth process of Nepal because all indicators of banking development have positive and significant impact on growth. The study results shed light on the fact that both the level of stock market development and the level of banking development can influence the economic growth of Nepal. This finding supports the notion of Levine (1996) which articulates that stock market and banking sector are independently as well as jointly significant in promoting economic growth.
\end{abstract}

Key Words: Banking Development, Stock Market Development, Economic Growth

\section{INTRODUCTION}

The relationship between financial sector development and economic growth has been one of the extensively discussed issues in finance and development literatures. The finance-growth nexus is not only a matter of academic debate but also a crucial policy issue. Financial development can be of two types - the bank-based development and the market-based development. The proponents of bank-based financial development believe that banks are better at managing liquidity risk and promote sound corporate control. These factors lead an efficient allocation of capital and ultimately boost up economic growth (Bencivenga \& Smith, 1991). In similar line, Rajan and Zingales (1998)

1. Dr. Rana is Lecturer at Tribhuvan University, Faculty of Management, Butwal Multiple Campus, Butwal. He is also a member of Finance Subject Committee at FOM, T.U. He can be reached at surryabrana@gmail.com 
argue that powerful banks may have the ability to persuade firms to release information about their activities and pay debts better than the stock markets. At early stages of establishment, firms usually face capital constraints, which may put at risk the firm's current and future activities. At this stage, banks become crucial to firms' growth because they can better provide external finance to new innovative projects than markets. Rajan and Zingales (1998) also assert that in the absence of efficient legal systems and sound institutions, powerful banks can force firms to repay their debts while markets cannot. For this reason, bank-based system is believed to be a better system to boost up economic growth.

In contrast, the supporters of market-based view argue that efficient markets positively impact growth, because stock market liquidity allows for easy and quick trade of assets. It also simultaneously allows savers to become less reluctant to give up their savings in markets while ensuring that firms have permanent access to capital (Levine \& Zerovs, 1996). Greenwood and Smith (1997) argue that high transaction and information costs associated with pulling funds from various savers to the end users can be overcome by the services provided by stock markets since it can reduce the costs associated with mobilizing savings and thus can improve investment in most productive technologies. Furthermore, Obstfeld (1995) argues that stock markets ease risk management, which improves the resource allocation and accelerates the rate of economic growth. In this way, the proponents of market-based system defend stock markets as crucial determinants for economic growth.

There are competiting views on the relative importance of bank-based and market-based financial development in predicting economic growth. Thus, main policy issue is: which type of financial development policy should the government priorotise? The proponents of the bank-based financial system argue that banks can avoid the shortcomings of the market-based financial systems. For example, the agency problem due to asymmetry of information between the actors is less severe in the bank-based system than in the market-based type. The market-based view, on the other hand, insists that a well-functioning stock markets foster growth and profit incentives and help in risk management more efficiently than the bank-based system does (Levine, 2002). The financial structure changes as a country goes through different stages of development. It is argued that at the advanced stages of development, the market-based structures are more effective than the bank-based ones in fostering economic growth in a country (Boyd \& Smith, 1998). Bencivenga, Smith and Starr (1996) demonstrate theoretically that a more developed stock market may provide liquidity that lowers the cost of foreign capital essential for development, especially in low-income countries that cannot generate sufficient domestic savings. However, arising from cross-country studies on relative importance of bank-based and market-based structure on predicting economic growth, Levine (1997 \& 2003) and Beck and Levine (2004) show that financial structure is irrelevant to economic growth. They assert that neither bank-based nor market-based financial structure alone can explain growth; rather it is the overall provision of financial services both in 
banks and capital market taken together that affect growth. In this sense, instead of bank and market substituting each other, they complement each other and contribute to economic growth.

Nepal has already undertaken financial sector reforms and structural adjustment programs. But, it is yet to emerge out of the status of least developed country. This situation calls for investigating into the role of bank-based and market-based financial development in the process of economic development of Nepal. In this backdrop, this study proposes a reasonable framework for studying some elements of endogenous growth that relate to the main aspects of functions of financial sector, especially stock market and banking sector. In particular, this study attempts to make two main contributions. First, it extends a simple model of Romer (1986), Lucas (1988), Rebelo (1991), and Pagano (1993) type of endogenous growth economy in order to incorporate the effect of financial sector development.

In the empirical arena, Bencivenga and Smith (1991) and Levine (1991) were among the first to propose endogenous growth models to identify the channels through which financial sector affects long-run economic growth. Both studies emphasized that financial sectors help diversify agents' liquidity and investment risk, attract more savings into productive investment and prevent the premature withdrawal of physical capital invested in the long-run projects. With the existence of financial markets and institutions, more capital can be kept in productive investments, which raises the rate of economic growth.

King and Levine (1993b) suggested another approach to identifying the channel of transmission between finance and growth. Their model identified innovation as the engine of growth. Financial markets and institutions evaluate the potential innovative projects, finance the most promising ones and monitor the carrying out of the investment. Therefore, an economy with well functioning financial markets will experience a higher growth rate of productivity.

In a modern economy, banks and stock markets constitute a major part of the financial system. Although they may perform different roles in the process of economic growth, their uniqueness is hardly emphasized within the framework of economic growth. The channel suggested by King and Levine (1993b) cannot distinguish between the roles of stock markets and banks. As far as capital accumulation is concerned, both stock markets and banks provide source of external financing for firms. For the function of resource allocation, both stock markets and banks create information to guide the allocation of resources. In this regard, based on the review of theoretical literature, this study argues that the degree to which financial sector, both stock market and bank, influence economic growth depends on how effectively they improve capital accumulation, facilitate resource mobilization and increase the productivity of capital investment. Second, this study attempts to estimate and test the model with regard to individual country Nepal. This study, therefore, proposes a different effort to investigate the role of market-based and bank-based development of financial sector on fostering the economic growth of Nepal. 
The specific issues this study attempts to resolve are: Does the stock market development explain economic growth in Nepal? Does the banking development explain economic growth in Nepal? Or, both of them affect growth? The rest of this paper is organized as follows: section II describes methodology used in the study; section III deals with study results and discussion; and finally section IV presents the conclusion and implications of the empirical findings.

\section{METHODOLOGY}

\section{The Finance-Augmented Endogenous Growth Model}

The modeling of financial markets and their growth implications are still in their early life. As cited in the theoretical literatures, there are three main channels through which financial sector development can influence the economic growth. First, financial sector development mobilizes and allocates resources to their efficient use. Second, financial sector development may change the saving rate and hence affect the physical capital accumulation. And, third, financial sector development increase the productivity of capital utilized in an economy. To capture the potential effects of financial sector development on economic growth, this study uses a simple framework of endogenous growth model as suggested by Romer (1986), Rebelo (1991) and Pagano (1993). The endogenous growth model explains the long-run growth rate of an economy on the basis of endogenous factors as against exogenous factors of the neoclassical growth theory. At steady states, the real economic growth rate $(G)$ is some composite of the social marginal productivity of capital $(A)$, the proportion of total savings that are mobilized to investment $(b)$, and the savings ratio (s). In identity form, a representation of the model can be written as:

\section{$G=\ln A+\ln b+\ln s$}

Pagano (1993) states three ideas underlying Equation (1) that explain the mechanisms by which financial sector development may induce endogenous economic growth: first it can raise $b$, the proportion of savings channeled to investment, and thus increases the mobilization and allocation of capital into productive use; second, it can raise $s$, the saving rate, thereby increasing physical capital accumulation; and lastly, it can increase $A$, the level of total factor productivity, by influencing economic efficiency or the level of technological progress. Thus, financial sector can affect economic growth by increasing the saving rate, the fraction of saving channeled to investment, and the social marginal productivity of investment.

In order to analyze empirically the strength of the relationship between bank sector and stock market development and the growth rate of economic activity in Nepal, the study begins with the simple endogenous growth model as given in Equation (1), in which economic growth $(G)$ is related to three equations that capture the effect of financial sector development on growth. The behavioral nature of these equations is as follows: 
First, it is assumed that behavior of $s$ and $b$ are influenced by some measurements of financial sector development as follows:

$$
\begin{aligned}
& \text { In } s_{t}=\varphi_{0}+\varphi_{1} F D_{t}+\eta_{t} \\
& \ln b_{t}=\delta_{0}+\delta_{1} F D_{t}+\mu_{t}
\end{aligned}
$$

In Equations (2) and (3), $F D_{t}$ is the vector of financial sector development measurement, $\eta_{t}$ and $\boldsymbol{\mu}_{t}$ are the white-noise error terms, and $t$ represents time period. The measures of financial sector development represent variables from both stock market development and banking development as explained in subsequent subsection of this study.

Second, financial sector development affects the behavior of $A$ by influencing economic efficiency or the level of technological progress. According to Rebelo (1991), the efficient production decisions are characterized by two conditions: the first one is static in the sense that it regards the optimal allocation of the existing capital stock and available efficiency of labor across the two activities; the second efficiency condition is dynamic in nature and concerns the decision of investing in physical capital versus human capital. Thus, the behavior of $A$ is also influenced by capitaloutput ratio and human capital accumulation as shown in Equation (4).

$$
\ln A=\rho_{0}+\rho_{1} F D_{t}+\rho_{2}\left(K / Y_{t}\right)+\rho_{3} H C_{t}+v_{t} \ldots \text { (4) }
$$

In Equation (4), $K / Y$ is the capital-output ratio, $H C_{t}$ is an indicator of human capital, and $\boldsymbol{v}_{\boldsymbol{t}}$ is white-noise error term. Substituting Equations (2), (3), and (4) into (1) yields the following empirical model:

$$
G=\alpha_{0}+\alpha_{1}\left(K_{t} / Y_{t}\right)+\alpha_{2} H C_{t}+\alpha_{3} F D_{t}+\varepsilon
$$

In Equation (5), $\varepsilon_{t}$ is white-noise error term. The basic argument in this model is that the saving and investment activities in the financial markets induce economic growth endogenously. There is one problem encountered in using the empirical model of Equation (5) that the time series data on capital stock are not readily available in case of most of the developing countries and so is the case of Nepal. One of the greatest difficulties in estimating the capital stock data is in determining the initial capital stock. Some studies such as King and Levine (1993a) base their estimate on an assumption of an initial capital stock of zero, and others such as Levine and Zerovs (1998) suggest deriving a guess of the initial capital stock in 1950, which assumes that a country was at its steady state capital output ratio in 1950. All these assumptions do not give a real picture of the capital stock accumulation. Therefore, following Ghura (1997) the investment-output ratio $(I / Y)$ has been used instead of capital-output ratio. Thus, Equation (5) appears in the following form:

$$
G=\alpha_{0}+\alpha_{1}\left(I_{t} / Y\right)+\alpha_{2} H C_{t}+\alpha_{3} F D_{t}+\varepsilon_{t} \quad \ldots(6)
$$

In Equation (6), the investment-output ratio is measured as gross fixed capital formation to GDP ratio, which indicates the level of investment relative to size of economy. It is to be noted that the stock of human capital is proxied empirically by many variables such as primary school enrollment rate, secondary school enrollment rate, total estimated average schooling years, and total labor force participation rate. Although none of these 
measures can perfectly represent human capital, there are many growth literatures (for example, Barro \& Lee, 1993; Nehru, Swanson \& Dubey, 1995, among others) which used average years of education as the proxy of human capital. Average years of schooling has been the most popular choice partly because of the availability of large database. Therefore, this study uses average years of scholling of adult people ages 25 years and above to incorporate the knowledge of human capital that is expected to contribute for output growth.

\section{Variable Measures}

\section{Economic Growth Varibles}

There are several measures of economic growth. For example, Levine and Zerovs (1996) used real per capita GDP growth as proxy of economic growth, whereas Levine and Zerovs (1998) used three measures- real per capita GDP growth, capital stock growth, and productivity growth- as the proxy measures of economic growth. As statekyd earlier, the data on capital stock in case of Nepal is not available. Further, productivity growth can only be obtained after determining capital stock growth. Thus, consistent with the growth literature (for example, Levine \& Zerovs, 1996, among others), this study employs the growth rate in per capita real GDP as a measure of economic growth.

\section{Stock Market Development Variables}

Following Demirguc-Kunt and Levine (1996), Demirguc-Kunt and Maksimovic (1996) and Levine and Zerovs (1996), this study uses stock market size, liquidity and stock market index as the indicators of stock market development. The study employs market capitalization adjusted for the size of economy as indicator of stock market size and termed as market capitalization ratio (MCR). Another important attribute of stock market development is the liquidity. To measure the liquidity, this study uses value traded adjusted for the size of the economy (GDP), termed as value traded ratio (VTR). Moreover, this study also employs all share price index published by Nepal Stock Exchange Limited, called NEPSE index, to measure the relative development of stock market over the period. NEPSE index used in this study is the fiscal year-end NEPSE index. It serves as benchmark for total equity market behavior in Nepal because it incorporates the change in total market capitalization of all companies' stocks listed in Nepal Stock Exchange Limited.

\section{Banking Development Variables}

With respect to banking development variables, traditionally, several studies (such as Goldsmith, 1969; McKinnon, 1973) used proxy for financial depth defined as broad money $\left(M_{2}\right)$ divided by GDPas one important indicator of banking development. However, King and Levine (1993a) argue that this measure does not indicate whether the liabilities are those of central banks, commercial banks or other financial intermediaries. Levine and Zerovs (1998), therefore, argue that the ratio of the value of domestic private credit to GDPmeasure improves upon traditional financial depth measures of banking development by isolating credit issued by banks, as opposed to credit issued by the central bank or other intermediaries, and by 
identifying credit to the private sector as opposed to credit issued to governments. In addition to these two measures, Levine, Loyaza and Beck (2000) also used the ratio of total bank assets to GDP as another indicator of banking development. This measure provides the evidence of the importance of financial services performed by banking sector relative to size of economy. Thus, consistent with these previous studies, this study employs three measures of banking development, namely, the ratio of the value of domestic private credit to $G D P$, known as bank credit ratio $(B C R)$, the total assets of commercial banks to $G D P$ ratio, termed as bank asset ratio $(B A R)$, and the ratio of broad money to $G D P$, termed as broad money ratio $\left(M_{2} R\right)$.

\section{Conditioning Information Set Variables}

Several empirical literatures on growth (such as Levine \& Zerovs, 1996; Levine, Loyaza \& Beck, 2000) have identified a large number of conditioning information set variables that are partially correlated with economic growth. However, inclusion of larger number of these variables as explanatory variables in the regressions results into loosing degree of freedom in empirical analysis especially for a study covering fewer observations. Therefore, due to this technical constraint, the study has limited the use of the macroeconomic conditioning variables to the ones most generally used in the literatures (for example, Barro, 1991; Mankiw, Romer \& Weil, 1992; Levine \& Renelt, 1992, among others). In this regard, the ratio of government recurrent expenditure to $G D P$, termed as government expenditure ratio (GER), has been used as an indicator of macroeconomic stability, and the sum of exports and imports as a share of $G D P$, also termed as import-export ratio (IER), has been used to capture the degree of openness of the economy. The purpose of using these conditioning information set variables is to reduce the chance that growth regression omits an important variable. Hence, the study finally estimates the Equation (7):

$$
G=\alpha_{0}+\alpha_{1}\left(I_{t} / Y_{t}\right)+\alpha_{2} H C_{t}+\alpha_{3} F D_{t}++\alpha_{4} G E R_{t}+\alpha_{5} I E R_{t}+\varepsilon_{t}
$$

This basic model has been empirically verified in several specifications of financial development indicators. The explanatory variable of the basic interest in this study is financial development indicator $(F D)$, which includes both banking development and stock market development indicators. If the coefficient estimates of these variables enter positively and significantly in the growth regression, it can be concluded that stock market and banking development can enhance the output growth, facilitating resource mobilization to most efficient use, and encouraging investment in highly productive activities, thereby accelerating real economic growth.

\section{Data Description}

The empirical results, in this study, are based on the analysis of economic and financial time series data derived from various sources. Data problem is more acute in conducting this type of study using time series of macroeconomic variables in Nepal. Nepal has not yet adopted the practice of announcing quarterly GDP. Therefore, the study results are based on annual time series of this variable indicating economic growth. 
Campbell and Perron (1991) argue that as far as the power of recent time series test is concerned, the span of data is much more important than the number of observations. Demetriades and Hussein (1996) also suggest that it is much more preferable to use fewer annual observations data covering longer period of time than using larger observations covering short span of time. Thus, the annual time series data used in this study covers 29 years of period from the fiscal year 1987/88 to 2015/16.

The GDP series from fiscal year $1987 / 88$ to $2001 / 02$ were derived from various issues of macroeconomic indicators published by Nepal Rastra Bank, and GDP series after 2002/03 were obtained from Government of Nepal, Ministry of Finance, Economic Survey 2015/16 and Economic Survey (2010/11), Statistical Tables Volume II. Market capitalization and annual value of shares traded data are also taken for the same period (1987/88 to 2015/16); but, Nepse index data has been taken since mid-July 1994 (23 observations) as Nepse started publishing index only in 1994. The data on stock market variables were retrieved from various issues of annual reports published by Nepal Stock Exchange Limited and Securities Board of Nepal including Quarterly Economic Bulletin Vol. 50, No. 4 MidJuly 2016 published by Nepal Rastra Bank. The data on banking sector variables such as total bank assets, domestic credit to private sectors, and broad money were obtained from various issues of Quarterly Economic Bulletin published by Nepal Rastra Bank. The total bank assets include the total assets of commercial banks. Other macroeconomic data on gross fixed capital formation, government recurrent expenditure, imports and exports were retrieved from various issues of Economic Survey, the Economic Survey Statistical Tables, Vol. II, and Quarterly Economic Bulletin, Vol. 50, No. 4, Mid-July 2016. The data on average years of education received by people ages 25 and above were obtained from UNESCO Institute of Statistics-2015, Human Development Report-2015 and various issues of Population Census of Nepal.

\section{STUDY RESULTS AND DISCUSSION}

\section{Results of Unit Root Test}

Before estimating the predictive power of stock market and banking sector development indicators on economic growth, it is necessary to ensure the stationarity in time series data used in the study. If a time series is non-stationary, or has unit root, the regression analysis carried out in a conventional way will produce spurious results. Wooldridge (2009) argues that in the presence of unit root in time series, there is no sense in which dependent and independent variables are related, but a regression using the usual $t$-statistic will often indicate a relationship in the presence of unit root in time series. The analysis, therefore, begins with the testing of unit root to confirm the stationarity in time series data. The study employs Augmented Dickey-Fuller (ADF) test proposed by Dickey and Fuller (1979) and Phillips-Perron (PP) test proposed by Phillips and Perron (1988).

Table 1 reports the results of unit root test based on both ADF test and PP test. As can be seen for level series, ADF tests fails to reject the null hypothesis of unit root for all series. Similarly, PP test also fails to reject the null hypothesis of unit root 
for all the series. However, the unit root seems to improve in first difference series for all variables, and hence all series are I(1) according to both ADF test and PP test. These tests reject the null hypothesis of unit root for all series in first difference either at 1 percent or 5 percent level. Thus, the results of unit root test suggest that, prior to estimating the regressions, it is necessary to transform all series using first difference operator to fix the stationarity in time series data.

Table 1

Results of Unit Root Test

\begin{tabular}{|c|c|c|c|c|}
\hline \multirow{2}{*}{ Variables } & \multicolumn{2}{|c|}{ ADF Test } & \multicolumn{2}{|c|}{ PP Test } \\
\hline & Level & First Difference & Level & First Difference \\
\hline GROWTH & -0.5203 & $-5.1748^{*}$ & -0.5270 & $-5.1819^{*}$ \\
\hline INV & 0.2172 & $-4.5526^{*}$ & 0.1810 & $-4.7026^{*}$ \\
\hline $\mathrm{HC}$ & -1.1011 & $-4.2377^{\star}$ & -1.0598 & $-4.2181^{*}$ \\
\hline MCR & -1.5303 & $-4.3676^{*}$ & -0.8151 & $-4.0732^{*}$ \\
\hline VTR & -1.7825 & $-4.4999^{*}$ & -1.5073 & $-7.4138^{*}$ \\
\hline NEPSE & -0.6442 & $-3.9788^{*}$ & -0.8825 & $-3.1082^{\star *}$ \\
\hline M2R & 0.6442 & $-6.2129^{\star}$ & 0.8789 & $-6.2129^{*}$ \\
\hline $\mathrm{BCR}$ & -1.0737 & $-3.4398^{* *}$ & -1.0298 & $-3.4822^{* *}$ \\
\hline BAR & -1.2986 & $-4.6150^{*}$ & -1.5548 & $-4.5936^{*}$ \\
\hline GER & -1.6038 & $-4.0565^{\star}$ & -1.7930 & $-5.0177^{\star}$ \\
\hline IER & -1.7815 & $-4.5349^{*}$ & -1.7095 & $-4.9762^{*}$ \\
\hline
\end{tabular}

Note. The reported values are test statistics. "*" indicates that result is significant at 1 percent level, and "**' indicates that result is significant at 5 percent.

\section{Results of Empirical Endogenous Growth Regression}

This study uses two-stage least square estimates (2SLS) to correct for the endogeneity of independent variables. In the first stage, 2SLS uses instrumental variables that are uncorrelated with the error terms to compute estimated values of the problematic predictors and then in second stage it uses those computed values to estimate a linear regression model of the dependent variable. Similarly, in time series regression, basic forms of models make use of the assumption that errors have the same variance across all observation points. When this is not the case, the errors are said to have heteroscedasticity, and this behavior will be reflected in the residuals estimated from a fitted model. Thus, White's heteroscedasticity consistent standard errors have been used to allow the fitting of a model that does contain heteroscedasticity residuals.

The study organizes the empirical examination on three measures of stock market development and three measures of banking development, individually as well as jointly. Moreover, the analyses also proceed for both with and without controlling for the effect of conditioning information set variables- macroeconomic stability and openness of economy. Thus, the study runs 21 basic regressions, where the dependent variable is growth rate in per capita real GDP. The regression results are reported in Table 2 through 6. 


\section{Market-based Development and Economic Growth}

The regression results in Table 2 represent the per capita real GDP growth as a function of stock market development indicators, both with and without controlling for the effect of conditioning variables.

Table 2

Estimated Results for Per Capita Real GDP Growth as a Function of Stock Market Development

\begin{tabular}{|c|c|c|c|c|c|c|}
\hline & $\begin{array}{c}\text { Regression } \\
1 \\
\end{array}$ & $\begin{array}{c}\text { Regression } \\
2 \\
\end{array}$ & $\begin{array}{c}\text { Regression } \\
3 \\
\end{array}$ & $\begin{array}{c}\text { Regression } \\
4 \\
\end{array}$ & $\begin{array}{c}\text { Regression } \\
5 \\
\end{array}$ & $\begin{array}{c}\text { Regression } \\
6 \\
\end{array}$ \\
\hline Constant & $\begin{array}{l}0.0091^{* *} \\
(2.1461)\end{array}$ & $\begin{array}{l}0.0130^{*} \\
(3.6165)\end{array}$ & $\begin{array}{c}-0.0016 \\
(-0.5715)\end{array}$ & $\begin{array}{c}0.0074 \\
(0.9325)\end{array}$ & $\begin{array}{c}0.0061 \\
(1.7308)\end{array}$ & $\begin{array}{l}0.0139^{*} \\
(5.2064)\end{array}$ \\
\hline INV & $\begin{array}{l}0.0781^{* *} \\
(2.6001)\end{array}$ & $\begin{array}{l}0.0847^{\star *} \\
(2.7411)\end{array}$ & $\begin{array}{l}0.1676^{*} \\
(3.5669)\end{array}$ & $\begin{array}{l}0.0769^{* *} \\
(2.6659)\end{array}$ & $\begin{array}{l}0.1559^{*} \\
(3.4916)\end{array}$ & $\begin{array}{l}0.1216^{\star *} \\
(2.4736)\end{array}$ \\
\hline $\mathrm{HC}$ & $\begin{array}{c}0.0084 \\
(1.0544)\end{array}$ & $\begin{array}{c}0.0075 \\
(0.8716)\end{array}$ & $\begin{array}{c}0.0029 \\
(0.2685)\end{array}$ & $\begin{array}{c}0.0034 \\
(0.6190)\end{array}$ & $\begin{array}{c}0.0066 \\
(0.7522)\end{array}$ & $\begin{array}{c}0.0029 \\
(0.7327)\end{array}$ \\
\hline MCR & $\begin{array}{l}0.0214^{*} \\
(4.3897)\end{array}$ & $\begin{array}{l}0.0264^{*} \\
(4.7922)\end{array}$ & & & & 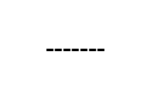 \\
\hline VTR & ------ & ----- & $\begin{array}{l}0.0119^{* *} \\
(2.3009)\end{array}$ & $\begin{array}{l}0.0116^{\star *} \\
(2.1182)\end{array}$ & 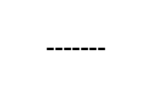 & ------ \\
\hline NEPSE & ------ & ------ & ----- & ----- & $\begin{array}{l}0.0167^{* *} \\
(2.3321)\end{array}$ & $\begin{array}{l}0.0125^{\star *} \\
(2.1289)\end{array}$ \\
\hline GER & ------ & $\begin{array}{c}0.0839 \\
(1.4629)\end{array}$ & & $\begin{array}{c}0.0505 \\
(0.5229)\end{array}$ & - & $\begin{array}{c}-0.1204 \\
(-0.7795)\end{array}$ \\
\hline IER & ------ & $\begin{array}{l}0.1152^{*} \\
(3.1146)\end{array}$ & ---- & $\begin{array}{l}0.1276^{*} \\
(3.5295)\end{array}$ & --- & $\begin{array}{l}0.1413^{*} \\
(4.0368)\end{array}$ \\
\hline R-Square & 0.7593 & 0.8481 & 0.7093 & 0.7879 & 0.7011 & 0.7514 \\
\hline Adj. $R^{2}$ & 0.7279 & 0.8119 & 0.6714 & 0.7374 & 0.6621 & 0.6921 \\
\hline F-Statistics & $24.1849^{*}$ & $23.4498^{*}$ & $18.7064^{*}$ & $15.6019^{*}$ & $17.9824^{*}$ & $12.6946^{*}$ \\
\hline Jarque-Bera & 0.9300 & 0.4786 & 1.1262 & 0.1343 & 1.3048 & 1.4972 \\
\hline $\begin{array}{l}\text { Serial Correlation } \\
\text { LM Test }\end{array}$ & 0.3610 & 0.4144 & 0.4131 & 0.3739 & 0.3754 & 0.3148 \\
\hline Heteroscedasticity Test: White & 3.8488 & 3.5248 & 3.0631 & 3.2929 & 4.1959 & 4.2134 \\
\hline No. of obs. after adjustment & 27 & 27 & 27 & 27 & 21 & 21 \\
\hline
\end{tabular}

Note. The reported values, in this table, are regression coefficients along with t-statistics in parentheses '()'. '*' indicates that results are significant at 1 percent level; and '**' indicates that results are significant at 5 percent level.

Regression 1 represents the economic growth as a function of stock market capitalization ratio. The market capitalization ratio enters the growth regression positively and significantly at 1 percent level. The significant explanatory power documented on behalf of market capitalization ratio in Regression 1 posits one important issue for further investigation that whether the explanatory power of market capitalization ratio losses with the inclusion of conditioning information set variables or the scenario remains unchanged. Regression 2 reveals the result of the regression of economic growth as 
a function of stock market capitalization ratio after controlling the effect of conditioning variables, namely government recurrent expenditure to GDP ratio, and import-export to $G D P$ ratio. As the results in regression 2 reveal, the market capitalization ratio still retains its significance at 1 percent level. Further, the inclusion of conditioning information set variables has improved the explanatory power of the model as indicated by R-square. These results are consistent with Levine and Zerovs (1998) who report that market capitalization ratio is a good predictor of economic growth.

Growth regression 3 reveals that the effects of value traded ratio enter significant at 5 percent level without controlling for the effect of macro-economic conditioning information set variables. With the inclusion of macroeconomic conditioning variables as regressors in regression 4 , the value traded ratio still retained its significance at 5 percent level to explain the economic growth of Nepal, though the size of coefficeint is slightly smaller. The result associated with positive and significant effect of value traded ratio is more confirmed to the model derived by Levine (1991) and Bencivenga, Smith, and Starr (1995), where they suggest that more liquid stock markets reduce the disincentives to investing in long-duration projects because investors can easily sell their stake in the project if they need their savings before the project matures. According to them, enhanced liquidity, therefore, facilitates investment in longer-term, higher-returns projects that boost productivity growth.

Regressions 5 and 6 reveal the regression results of economic growth proxied by per capita real GDP growth on the next measure of stock market development, namely the NEPSE index. Without controlling for the effect of macroeconomic conditioning information set variables in regression 5, the NEPSE index explains the economic growth of Nepal and the result is significant at 5 percent level. With the inclusion of conditioning variables in regression 6 , the NEPSE index again maintains its significance as the regression coefficent of NEPSE is positive and significant at 5 percent level.

Moreover, study also reveals significant effect of investment-output ratio on economic growth in all regressions 1 through 6 at least at 5 percent level. These documentations are consistent to the notion of economic growth models (such as Lucas, 1988), which assert that higher rate of investment is necessary to ensure long-run economic growth of the country. Furthermore, though not significant, the regression coefficient of the stock of human capital enters with consistent positive sign in regression 1 through 6 . This documentation is consistent to Mankiw, Romer and Weil (1992), Barro and Sala-I-Martin (1995), among others, who suggest an important link between the investment in human capital accumulation and economic growth. As it has been already stated, the stock of human capital in this study is proxied by the average years of schooling of adult population. The improved schooling of people in Nepal has been a central part of its development startegies, and the evidence show significant improvements in school attianment in recent decades (MoE, 2015). However, as Hanushek (2013) argues, expansion of scholl attainment does not guarantee improved economic condition. Instead, the impact of human capital becomes stronger when the focus turns to the role of school quality. Thus, consistent with the view of Hanushek (2013), the result associated with the role of human capital in this study explores the need to focus on school quality in Nepal. 
The regression results in Table 2 posit some important remarks associated with the effects of government recurrent expenditure ratio and imports-exports ratio. The government recurrent expenditure ratio does not enter significantly in all regressions and the effect is somewhere negative though not significant. The endogoneous growth models, such as Barro (1990), predict that only the productive government expenditures will positively affect the long-run growth rate. Therefore, the composition of government expediture is important rather than the size in affecting economic growth. In case of Nepal, it has been noticed that the share of government capital expenditure is on decreasing trend mainly after 1990s. The share of economic services expenditure is also on decresing trend with the rapid increase in government expenditure on loan repayment and interest payment (Mainali, 2012). In consistent to the findings of Barro and Sala-I-Martin (1995), and others, one possible explanation of the result documented in this study on behalf of the role of government expenditure is that since most of the government expenditures in Nepal are financed with tax revenues, the taxes required to finance government expenditure deform incentives, and reduce efficient resource allocation and the level of output. Thus, this variable is not the significant predictor of per capita real GDP growth in Nepal.

With respect to the effects of import-export to $G D P$ ratio, the result is consistent with Coe and Helpman (1995) who documented that the countries with higher imports and exports propensity have higher productivity growth. They suggest that higher degree of openness of the economy tends to improve more technical progress and attract more income and savings thus contributing positively towards productivity growth of the nation. Coe and Helpman (1995) further argue that imports contribute toward positive productivity growth through the channel of introducing new technological innovation. Particularly, other things remain the same, the countries with higher imports of capital goods are faster in speed of the output growth process.

All regressions 1 through 6 explain at least 70 percentage variation associated with growth rate in per capita real $G D P$ and F-statistic also explains the joint significance of model at 1 percent level. Particularly, it rejects the null hypothesis of no explanatory power for the regression as a whole at the 1 percent level in all the regressions. The tests of residuals also show the satisfactory results. Jarque-Bera test of normality of residuals shows no sufficient evidence to reject the null hypothesis that residuals are normally distributed. Similarly, Breusch-Godfrey serial correlation LM test accepts the null hypothesis of no serial correlation. Additionally, the White's heteroscedasticity test reveals no sufficient evidence to reject the null hypothesis of homoscedasticity of residuals.

To sum up, the regressions 1 through 6 support the hypothesis that stock market development has positive effects on the economic growth in Nepal and all indicators of stock market development have significant predictive power in explainig economic growth. Among the three indicators of stock market development, the market capitalization ratio better predicts the economic growth in Nepal as the size of the coefficeint is larger and highly significant than the coefficeints of other indicators of stock market development. The evidences documented in regressions 1 through 6 
confirm to the prediction of Atje and Jovanovic (1993), Harris (1997), and Levine and Zerovs (1996, 1998), among others, who observed positive and significant effect of stock market development on economic growth.

\section{Bank-based Development and Economic Growth}

The regression results in Table 3 represent the per capita real GDP growth as a function of banking development indicators. Regression 7 represents the economic growth as a function of broad money to GDP ratio. As can be seen, the broad money to GDP ratio enters the growth regression positively and significantly at 1 percent level. Regression 8 reveals the result of the regression of economic growth as a function of broad money to GDP ratio after controlling the effect of government expenditure to GDP and import-export to GDP. The broad money to GDP ratio still retains its explanatory power but is significant at 5 percent level as opposed to 1 percent level in regression 7 .

Table 3

Estimated Results for Per Capita Real GDP Growth as a Function of Banking Development

\begin{tabular}{|c|c|c|c|c|c|c|}
\hline & $\begin{array}{c}\text { Regression } \\
7 \\
\end{array}$ & $\begin{array}{c}\text { Regression } \\
8 \\
\end{array}$ & $\begin{array}{c}\text { Regression } \\
9 \\
\end{array}$ & $\begin{array}{c}\text { Regression } \\
10 \\
\end{array}$ & $\begin{array}{c}\text { Regression } \\
11 \\
\end{array}$ & $\begin{array}{c}\text { Regression } \\
12 \\
\end{array}$ \\
\hline & $-0.0049^{\star *}$ & $0.0132^{*}$ & $-0.0052^{*}$ & 0.0063 & $-0.0062^{*}$ & 0.0016 \\
\hline constant & $(-2.5729)$ & $(4.9381)$ & $(-3.2654)$ & $(0.6763)$ & $(-3.8284)$ & $(0.3084)$ \\
\hline INI & $0.1388^{* *}$ & $0.1197^{\star *}$ & $0.1288^{* *}$ & $0.1207^{\star *}$ & $0.1617^{\star *}$ & $0.1748^{*}$ \\
\hline IIVV & $(2.1456)$ & $(2.1129)$ & $(2.3551)$ & $(2.3544)$ & $(2.7417)$ & (3.3292) \\
\hline $\mathrm{HC}$ & 0.0105 & 0.0038 & 0.0105 & 0.0067 & 0.0079 & 0.0093 \\
\hline$\Pi$ & $(1.0483)$ & $(1.0205)$ & $(1.1204)$ & $(0.4239)$ & $(0.7439)$ & $(1.3736)$ \\
\hline M2R & $\begin{array}{l}0.1975^{\star} \\
(3.1389)\end{array}$ & $\begin{array}{l}0.0768^{* *} \\
(2.3041)\end{array}$ & & & & \\
\hline $\mathrm{BCR}$ & ------ & ----- & $\begin{array}{l}0.1057^{\star *} \\
(2.7399)\end{array}$ & $\begin{array}{l}0.0869^{* *} \\
(2.7020)\end{array}$ & & \\
\hline BAR & 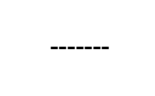 & ----- & - & ------ & $\begin{array}{l}0.1051^{* *} \\
(2.0754)\end{array}$ & $\begin{array}{l}0.1285^{\star} \\
(3.6685)\end{array}$ \\
\hline GER & ------ & $\begin{array}{c}-0.0768 \\
(-0.6172)\end{array}$ & & $\begin{array}{c}-0.1942 \\
(-0.7988)\end{array}$ & & $\begin{array}{c}0.1925 \\
(1.0413)\end{array}$ \\
\hline IER & ------ & $\begin{array}{l}0.1319^{*} \\
(3.8872)\end{array}$ & ------ & $\begin{array}{l}0.1446^{*} \\
(4.2317)\end{array}$ & - & $\begin{array}{l}0.1564^{*} \\
(4.8633)\end{array}$ \\
\hline R-Square & 0.7747 & 0.8442 & 0.7659 & 0.8154 & 0.7163 & 0.8053 \\
\hline Adj. $R^{2}$ & 0.7453 & 0.8071 & 0.7354 & 0.7714 & 0.6793 & 0.7589 \\
\hline F-Statistics & $26.3620^{*}$ & $22.7576^{*}$ & $25.0828^{*}$ & $18.5519^{*}$ & $19.3572^{*}$ & $17.3716^{*}$ \\
\hline Jarque-Bera & 0.6791 & 0.5512 & 0.7111 & 0.5284 & 0.9809 & 0.4683 \\
\hline Serial Correlation LM Test & 0.3309 & 0.4087 & 0.4674 & 0.4129 & 0.3595 & 0.4742 \\
\hline Heterosce-dasticity Test: White & 4.2574 & 4.3738 & 3.2316 & 4.1064 & 3.2493 & 3.6725 \\
\hline No. of obs. after adjustment & 27 & 27 & 27 & 27 & 27 & 27 \\
\hline
\end{tabular}

Note. Reported values are regression coefficients along with t-statistics in parentheses '()' "*' indicates that results are significant at 1 percent level; and "**' indicates that results are significant at 5 percent level. 
Growth regressions 9 and 10 reveal the results of per capita real GDP growth as a function of next indicator of banking development, namely domestic private credit to GDP ratio. In both regressions, the effect of domestic private credit to GDP ratio enters positively and significantly at 5 percent level. Regressions 11 and 12 reveal the regression results of growth rate in per capita real GDP on total assets of commercial banks to GDP ratio. Without controlling for the effect of macroeconomic conditioning information set variables, the total assets of commercial banks to GDP ratio explains the economic growth of Nepal and the result is significant at 5 percent level. With the inclusion of conditioning variables in regression 12, the total assets of commercial banks to GDP ratio again retains its significance but at 1 percent level. With respect to the effect size of other variables, the results revealed the same picture as in the case of regressions 1 through 6 .

To sum up, the regressions 7 through 12 also support the hypothesis that economic growth is positively related with banking development in Nepal because all indicators of banking development have significant predictive power in explaining economic growth in Nepal. In particular, this result establishes the important role of bank-based financial development in determining the economic growth and confirms the strong positive and statistically significant relationship between banking development and economic growth in Nepal. The evidences documented in regressions 7 through 12 confirm to the findings of Nyasha and Odhiambo (2015), among others, who documented a significant role of bank-based financial system in predicting economic growth.

\section{Joint Effect of Market-based and Bank-based Development on Growth}

The two stage least square estimates in the framework of endogenous growth model in previous sections suggest that stock market development and banking development can independently explain economic growth of Nepal over the study period. These documentations posit one issue for further investigation whether stock market development variables retain their significance when considered jointly with banking development variables or banking development variables retain their significance when considered jointly with stock market development variables. Hence, this study further attempts to estimate additional regressions taking together these variables, one among the stock market development variables and one among the banking development variables, to examine the joint significance of stock market development and banking development to explain economic growth of Nepal over the study period. The regression results are reported in Table 4 through 6.

Regression 13 estimates the per capita real GDP growth as the function of market capitalization ratio and broad money to GDP ratio, after controlling for the effect of government recurrent expenditure to GDP ratio and import-export to GDP ratio. The basic variables of interest in this model are market capitalization ratio and broad money to GDP ratio. Both of these regressors enter the growth regression positively and significantly at 1 percent level. In regression 14, again market capitalization ratio is jointly used as 
regressor with another measure of banking development indicator defined as the ratio of domestic private credit to GDP. With the inclusion of domestic private credit to GDP ratio in the place of broad money to GDP, the explanatory power of the model has been slightly declined as compared to regression 13. More interesting part of this regression is that explanatory power of market capitalization ratio has been erroded while used jointly with domestic private credit to GDP ratio than with broad money to GDP ratio in regression 13. Regression 15 also gives the same conclusion when market capitalization ratio and total assets of commercial banks to GDP ratio are jointly considered as regressors. Both of these variables maintain their significance at 5 percent level to predict growth rate in per capita real GDP in Nepal over the study period.

Table 4

Estimated Regression Results for Per Capita Real GDP Growth as a Function of Market Capitalization Ratio and Banking Development Indicators

\begin{tabular}{|c|c|c|c|}
\hline & Regression & Regression & Regression \\
\hline & 13 & 14 & 15 \\
\hline \multirow[t]{2}{*}{ Constant } & 0.0008 & 0.0004 & 0.0012 \\
\hline & $(0.7461)$ & $(0.4625)$ & $(0.9306)$ \\
\hline \multirow[t]{2}{*}{ INV } & $0.1126^{\star *}$ & $0.1334^{*}$ & $0.1195^{\star *}$ \\
\hline & $(2.3337)$ & (3.3944) & $(2.3529)$ \\
\hline \multirow[t]{2}{*}{$\mathrm{HC}$} & 0.0026 & 0.0034 & 0.0022 \\
\hline & $(1.0431)$ & $(0.9937)$ & $(0.6382)$ \\
\hline \multirow[t]{2}{*}{ MCR } & $0.0296^{*}$ & $0.0203^{* *}$ & $0.0192^{\star \star}$ \\
\hline & (3.0208) & $(2.6702)$ & $(2.5814)$ \\
\hline \multirow[t]{2}{*}{$M 2 R$} & $0.0764^{*}$ & ------- & ------- \\
\hline & (3.3759) & & \\
\hline \multirow[t]{2}{*}{ BCR } & ------- & $0.0850^{* *}$ & ------- \\
\hline & & $(2.5688)$ & \\
\hline \multirow[t]{2}{*}{ BAR } & ------- & ------- & $0.1125^{\star *}$ \\
\hline & & & $(2.6154)$ \\
\hline \multirow[t]{2}{*}{ GER } & -0.1391 & -0.1404 & 0.1218 \\
\hline & $(-1.1531)$ & $(-1.1797)$ & $(1.0152)$ \\
\hline \multirow[t]{2}{*}{ IER } & $0.1857^{\star}$ & $0.1692^{*}$ & $0.1422^{*}$ \\
\hline & $(6.2318)$ & $(5.8702)$ & $(5.0318)$ \\
\hline R-Square & 0.8783 & 0.8659 & 0.8349 \\
\hline Adj. $R^{2}$ & 0.8418 & 0.8257 & 0.7854 \\
\hline F-Statistics & $24.0564^{*}$ & $21.5237^{*}$ & $16.8564^{*}$ \\
\hline Jarque-Bera & 0.5199 & 0.8515 & 0.8384 \\
\hline Serial Correlation LM Test & 0.3231 & 0.3134 & 0.4123 \\
\hline Heteroscedasticity Test: White & 3.0807 & 3.2219 & 4.1035 \\
\hline No. of observations after adjustment & 27 & 27 & 27 \\
\hline
\end{tabular}

Note. Reported values are regression coefficients along with $t$-statistics in parentheses '( )'. '*' indicates that results are significant at 1 percent level; and '**' indicates that results are significant at 5 percent level. 
As in all previous regressions, the effect of investment-output ratio is positive and significant at least at 5 percent level and the effect of stock of human capital, though has positive coefficient, is not significant. Out of two macroeconomic conditioning information set variables, the import-export to GDP ratio again enters growth regression positively and significantly at 1 percent level, the result consistent to those documented in all previous regressions.

Table 5

Estimated Regression Results for Per Capita Real GDP Growth as a Function of Value Traded Ratio and Banking Development Indicators

\begin{tabular}{|c|c|c|c|}
\hline & $\begin{array}{c}\text { Regression } \\
16\end{array}$ & $\begin{array}{c}\text { Regression } \\
17\end{array}$ & $\begin{array}{c}\text { Regression } \\
18\end{array}$ \\
\hline Constant & $\begin{array}{c}0.0012 \\
(0.4221)\end{array}$ & $\begin{array}{c}0.0009 \\
(0.4058)\end{array}$ & $\begin{array}{c}0.0014 \\
(1.2612)\end{array}$ \\
\hline INV & $\begin{array}{l}0.1144^{\star *} \\
(2.3412)\end{array}$ & $\begin{array}{l}0.1396^{\star} \\
(3.4687)\end{array}$ & $\begin{array}{l}0.1240^{* *} \\
(2.5736)\end{array}$ \\
\hline $\mathrm{HC}$ & $\begin{array}{c}0.0029 \\
(0.6542)\end{array}$ & $\begin{array}{c}0.0038 \\
(0.6992)\end{array}$ & $\begin{array}{c}0.0024 \\
(0.6763)\end{array}$ \\
\hline VTR & $\begin{array}{l}0.0122^{* *} \\
(2.3462)\end{array}$ & $\begin{array}{l}0.0121^{* *} \\
(2.2990)\end{array}$ & $\begin{array}{l}0.0119^{* *} \\
(2.1865)\end{array}$ \\
\hline M2R & $\begin{array}{l}0.0760^{* *} \\
(2.2215)\end{array}$ & ------ & ------ \\
\hline $\mathrm{BCR}$ & ------ & $\begin{array}{c}0.1158^{*} \\
(3.4211)\end{array}$ & ------ \\
\hline BAR & ------ & ------ & $\begin{array}{l}0.1308^{* *} \\
(2.7251)\end{array}$ \\
\hline GER & $\begin{array}{c}-0.0824 \\
(-0.6371)\end{array}$ & $\begin{array}{c}-0.0744 \\
(-0.6160)\end{array}$ & $\begin{array}{c}0.0664 \\
(0.5163)\end{array}$ \\
\hline IER & $\begin{array}{l}0.1947^{*} \\
(6.5351)\end{array}$ & $\begin{array}{c}0.1795^{\star} \\
(5.9291)\end{array}$ & $\begin{array}{c}0.1986 * \\
(6.6805)\end{array}$ \\
\hline R-Square & 0.7961 & 0.7616 & 0.7536 \\
\hline Adj. $R^{2}$ & 0.7349 & 0.6901 & 0.6797 \\
\hline F-Statistics & $13.0145^{*}$ & $10.6487^{*}$ & $10.1948^{*}$ \\
\hline Jarque-Bera & 0.3331 & 0.8117 & 0.7653 \\
\hline Serial Correlation LM Test & 0.4967 & 0.4237 & 0.4555 \\
\hline Heteroscedasticity Test: White & 5.1017 & 5.0471 & 5.1190 \\
\hline No. of observations after adjustment & 27 & 27 & 27 \\
\hline
\end{tabular}

Note. Reported values are regression coefficients along with t-statistics in parentheses ' ()'. '“' indicates that results are significant at 1 percent level; and "**' indicates that results are significant at 5 percent level.

The results of regression 13 through 15 provide further evidence on the role of market capitalization ratio in explaining per capita real GDP growth of Nepal. The market capitalization ratio in all regressions demonstrates its strong predictability even after controlling for banking development effects. Thus, market capitalization ratio can be considered a robust predictor of economic growth of Nepal. 
Table 5 provides an estimate of the role of next measure of stock market development, the value traded ratio, jointly with the banking development indicators. One interesting part of these regressions is that explanatory power of value traded ratio jointly with broad money to GDP (in regression 16), with domestic private credit to GDP (in regression 17), and with total assets of commerical banks to GDP (in regression 18) still holds significant at 5 percent level in all regressions. The effect of domestic private credit to GDP (regression 17) is positive and significant at 1 percent level while the effects of broad money to GDP (regression 1) and total assets of commercial banks to GDP (regression 18) are positive and significant at 5 percent level.

Table 6

Estimated Regression Results for Per Capita Real GDP Growth as a Function of NEPSE Index and Banking Development Indicators

\begin{tabular}{|c|c|c|c|}
\hline & $\begin{array}{c}\text { Regression } \\
19\end{array}$ & $\begin{array}{l}\text { Regression } \\
20\end{array}$ & $\begin{array}{c}\text { Regression } \\
21\end{array}$ \\
\hline Constant & $\begin{array}{c}0.0011 \\
(0.6616)\end{array}$ & $\begin{array}{l}0.0128^{\star *} \\
(2.4058)\end{array}$ & $\begin{array}{c}0.0031 \\
(0.9923)\end{array}$ \\
\hline INV & $\begin{array}{l}0.1391^{*} \\
(3.4481)\end{array}$ & $\begin{array}{l}0.1215^{\star *} \\
(2.4186)\end{array}$ & $\begin{array}{l}0.1209^{* *} \\
(2.4003)\end{array}$ \\
\hline $\mathrm{HC}$ & $\begin{array}{c}0.0038 \\
(1.6345)\end{array}$ & $\begin{array}{c}0.0037 \\
(0.8699)\end{array}$ & $\begin{array}{c}0.0026 \\
(0.6455)\end{array}$ \\
\hline NEPSE & $\begin{array}{l}0.0108^{* *} \\
(2.1222)\end{array}$ & $\begin{array}{l}0.0119^{* *} \\
(2.3286)\end{array}$ & $\begin{array}{l}0.0121^{* *} \\
(2.6642)\end{array}$ \\
\hline M2R & $\begin{array}{c}0.1173^{*} \\
(3.7714)\end{array}$ & ------ & ------ \\
\hline BCR & ----- & $\begin{array}{l}0.1208^{*} \\
(3.5115)\end{array}$ & ------ \\
\hline BAR & ----- & ------ & $\begin{array}{c}0.1138^{*} \\
(3.5006)\end{array}$ \\
\hline GER & $\begin{array}{c}0.1515 \\
(0.9436)\end{array}$ & $\begin{array}{c}0.1379 \\
(0.8452)\end{array}$ & $\begin{array}{c}0.1367 \\
(0.8427)\end{array}$ \\
\hline IER & $\begin{array}{l}0.1721^{*} \\
(5.1503)\end{array}$ & $\begin{array}{c}0.1971^{*} \\
(5.3789)\end{array}$ & $\begin{array}{l}0.2051^{*} \\
(6.8321)\end{array}$ \\
\hline R-Square & 0.8147 & 0.7725 & 0.7637 \\
\hline Adj. $R^{2}$ & 0.7353 & 0.6750 & 0.6624 \\
\hline F-Statistics & $10.2586^{*}$ & $7.9231^{*}$ & $7.5411^{*}$ \\
\hline Jarque-Bera & 0.5781 & 0.7287 & 0.6333 \\
\hline Serial Correlation LM Test & 0.4698 & 0.4545 & 0.4773 \\
\hline Heteroscedasticity Test: White & 6.7227 & 6.5104 & 6.1442 \\
\hline No. of Obs. after adjustment & 21 & 21 & 21 \\
\hline
\end{tabular}

Note. Reported values are regression coefficients along with $t$-statistics in parentheses '()'. '“' indicates that results are significant at 1 percent level; and '**' indicates that results are significant at 5 percent level. 
The coefficients of value traded ratio enter positively and significantly in all growth regressions. The results have implications for a variety of theoretical models. The significant positive relation between stock market liquidity measured by value traded ratio and rate of economic growth confirms the theoretical prediction of Levine (1991) and Bencivenga, Smith and Starr (1995). Moreover, the broad money to GDP ratio, domestic private credit to GDP ratio and total assets of commercial banks to GDP ratio still remain as good predictors of economic growth of Nepal even after controlling for the effect of conditioning information set variables and stock market development indicators. These results are also consistent to Levine and Zerovs (1998), where they documented that banking development and stock market liquidity are both good predictors of economic growth.

Table 6 reports the estimated results of the regressions of growth rate in per capita real GDP on next measure of stock market development, NEPSE index, jointly with each of the banking development variables.

The results reported in Table 6 again give a robust scenario on the effects of these regressors in explaining economic growth of Nepal. In all regressions, the effect of NEPSE index is positive and statistically significant at 5 percent level, while the effects of banking development indicators are positive and significant at 1 percent level. Moreover, bank development effects are stronger than stock market development effects. One possible explanation of robust bank development effects in this study coincide with Rajan and Zingales (1998), who argue that bank effects are stronger in weak legal systems with poor institutional infrastructure. Similarly, this result is also consistent with the arguments that bank effects are more strong when the economy is dominated by small firms (Petersen \& Rajan, 1995), and when the economy is in early stage of development (Chakraborty \& Ray, 2006).

The effects of investment-output ratio in all regressions are significant at least at 5 percent level and the effects of import-export to GDP ratio is robustly significant at 1 percent level. The stock of human capital and government expenditure to GDP ratio again do not reveal their statistical significance to explain economic growth in Nepal.

Overall, the results suggest that stock market size proxied by the market capitalization ratio, stock market liquidity proxied by the value traded ratio, NEPSE index, financial depth proxied by broad money to GDP ratio, bank credit ratio proxied by the ratio of domestic private credit to $G D P$, and bank asset ratio proxied by the ratio of total assets of commercial banks to GDP are the robust predictors of the growth rate in per capita real GDP in Nepal. The results provide sufficient evidence to support the hypothesis that stock market and banking development are jointly significant in promoting economic growth in Nepal. Thus, to understand the relationship between financial systems and economic growth, there is a need of theories in which stock markets and banks arise together to provide different bundles of financial services. 


\section{CONCLUSION AND IMPLICATIONS}

This study examined the empirical relationship between economic growth and various measures of stock market and banking development. The study finds that stock market size, liquidity and banking development measures predict the economic growth in the context of Nepal over sample period 1987/88 to 2015/16. The study's findings with respect to the stock market size and stock market liquidity confirm to earlier studies such as Atje and Jovanovic (1993) who found large growth enhancing effects of stock market on economic growth, and Levine and Zerovs (1996) who found that stock market development is strongly and positively correlated with economic growth even after controlling for other growth influencing factors. Similalry, the study results show the important role of banking development on economic growth process of Nepal because all indicators of banking development have positive and significant impact on growth. The study results shed light on the fact that both the level of stock market development and the level of banking development can influence the economic growth of Nepal. This finding supports the notion of Levine (1997) which articulates that stock market and banking sector are independently as well as jointly significant in promoting economic growth.

Larger banking development effects than that of stock market obsereved in this study suugest that the stock market is to be restructured more as efficient tools of domestic resource mobilization with policies and measures adopted to increase stock market depth and competitiveness. Stock market reforms agenda such as reduction of costs of intermediation and floating new issues, adoption of measures and strategies to strengthen and enhance official supervision of trading in the stock market are necessary to be implemented effectively in Nepal to make the stock market more growth enhancing. With respect to larger banking development effects on economic growth, findings of this study can have important implication for the policy recommendation. Indeed, Nepal should establish a better developed financial system with a more efficient allocation of credit in order to sustain economic growth. As the effect of bank credit ratio is larger, Nepal can reduce its dependency on foreign credit replacing it by domestic credit for better economic health in future. In the environment of low foreign direct inflow in Nepal, domestic private sector can only serve as a major partner for productive investment.

Finally, the study results indicate that financial development plays a critical role in the Nepalese economy. Since the advent of multiparty democracy after 1990, Nepalese financial system has undergone massive restructuring in the line with both bankbased and market-based liberalization reforms. These reforms have made Nepalese financial market better to some extent in providing financial infrastructure and services. However, international best practices are still to be adopted to increase the efficiency and competency of financial institutions and markets. Therefore, there is a need to continue with these reforms in order to enable it contribute effectively to economic growth.

To sum up, although this part of study does not establish the direction of causal 
relationship between financial development and economic growth, the results show that both, the stock market development and banking development, are good predictor of economic growth in Nepal. As Demetriades and Andrianova (2004) explain, the existence of a developed financial system is a precondition for the country to materialize new innovations and exploit its resources efficiently. In this way, financial development is seen as a facilitator of economic growth, rather than as a deep determinant of growth. Thus, this study's results support the view that services provided by banks and stock market are important for facilitating long-run output growth of Nepal.

\section{REFERENCES}

Atje, R., \& Jovanovic, B. (1993). Stock markets and development. European Economic Review, 37(2-3), 632-640.

Barro, R. J. (1990). Government spending in a simple model of endogenous growth. The Journal of Political Economy, 98(5), 103-215.

Barro, R. J. (1991). Economic growth in a cross section of countries. The Quarterly Journal of Economics, 106(2), 407-443.

Barro, R. J., \& Lee, J. W. (1993). Institutional comparisons of educational attainment. Journal of Monetary Economics, 32(3), 363-394.

Barro, R. J., \& Sala-I-Martin, X. (1995). Economic Growth. New York: McGraw Hill.

Beck, T., \& Levine, R. (2004). Stock markets, banks, and growth: Panel evidence. Journal of Banking and Finance, 28(3), 423-442.

Bencivenga, V. R., \& Smith, B. D. (1991). Financial intermediation and endogenous growth. Review of Economic Studies, 58(2), 195-209.

Bencivenga, V. R., Smith, B. D. \& Starr, R. M. (1995). Transaction costs, technological choice, and endogenous growth. Journal of Economic Theory, 67(1), 53-177.

Bencivenga, V. R., Smith, B. D. \& Starr, R. M. (1996). Equity markets, transaction costs and capital accumulation: An illustration. World Bank Economic Review, 10(2), 241-265.

Boyd, J. H., \& Smith, B. D. (1998). The evolution of debt and equity markets in economic development. Economic Theory, 12(3), 519-560.

Campbell, J., \& Perron, P. (1991). Pitfalls and opportunities: What macroeconomists should know about unit roots. In O. J. Blanchard \& S. Fisher (Eds.), NBER Macroeconomics Annual. Cambridge, MA: MIT Press.

Chakraborty, S., \& Ray, T. (2006). Bank-based versus market-based financial system: A growth theoretic analysis. Journal of Monetary Economics, 53(2), 329-350.

Coe, D., \& Helpman, E. (1995). International R\&D spillovers. European Economic Review, 39(5), 859-887.

Demetriades, P., \& Andrianova, S. (2004). Finance and growth: What we know and what we need to know. In C. A. E. Goodhart (Ed.), Financial Development and Economic Growth: Explaining the Links. U.K.: Palgrave Macmillan

Demetriades, P., \& Hussein, K. A. (1996). Does financial development cause economic growth? Time series evidence from 16 countries. Journal of Development Economics, 51(2), 387-411.

Demirguc-Kunt, A., \& Levine, R. (1996). Stock market development and financial intermediaries: Stylized facts. The World Bank Economic Review, 10(2), 291-321.

Demirguc-Kunt, A., \& Maksimovic, V. (1996). Stock market development and financing choices of firms. The World Bank Economic Review, 10(2), 341-369. 
Dickey, D. A., \& Fuller, W. A. (1979). Distribution of the estimators for autoregressive time series with a unit root. Journal of the American Statistical Association, 74(366), 427-431.

Ghura, D. (1997). Private investment and endogenous growth: Evidence from Cameroon. IMF Working Paper No. 165. International Monetary Fund, Washington DC, United States.

Goldsmith, R. W. (1969). Financial Structure and Development. New Haven, Coon: Yale University Press.

Greenwood, J., \& Smith, B. D. (1997). Financial markets in development, and the development of financial markets. Journal of Economic Dynamics and Control, 21, 145-181.

Hanushek, E. A. (2013). Economic growth in developing countries: The role of human capital. Economics of Education Review, 37, 204-212.

Harris, R. (1997). Stock market and development: A reassessment. European Economic Review, 41(1), 139-146.

King, R. G., \& Levine, R. (1993a). Finance, entrepreneurship and growth: Theory and evidence. The Journal of Monetary Economics, 32(3), 513-542.

King, R. G., \& Levine, R. (1993b). Finance and growth: Schumpeter might be right. Quarterly Journal of Economics, 108(3), 717-737.

Levine, R. (1991). Stock markets, growth and tax policy. Journal of Finance, 46(4), 1445-1465.

Levine, R. (1997). Financial development and economic growth: Views and agenda. Journal of Economic Literature, 35, 688-726.

Levine, R. (2002). Bank based or market based financial systems: Which is better? Journal of Financial Intermediation, 11(4), 139-157.

Levine, R. (2003). More on finance and growth: More finance more growth. Federal Reserve Bank of St Louis Review, 85(4), 31-46.

Levine, R., Loyaza, N., \& Beck, T. (2000). Financial intermediation and economic growth: Causality and causes. Journal of Monetary Economics, 46(1), 31-77.

Levine, R., \& Renelt, D. (1992). A sensitivity analysis of cross-country growth regressions. American Economic Review, 82(4), 942-963.

Levine, R., \& Zervos, S. (1996). Stock market development and long-run growth. The World Bank Economic Review, 10(2), 323-339.

Levine, R., \& Zervos, S. (1998). Stock market, banks, and economic growth. American Economic Review, 88(3), 537-558.

Lucas, R. E. (1988). On the mechanics of economic development. Journal of Monetary Economics, 22(1), 3-42.

Mainali, P. K. (2012). Government expenditure and economic growth in Nepal. The Economic Journal of Nepal, 35(4), 215-234.

Mankiw, N., Romer, D., \& Weil, D. (1992). A contribution to the empirics of economic growth. Quarterly Journal of Economics, 107(2), 407-437.

McKinnon, R. (1973). Money and Capital in Economic Development. Washington D.C.: Brookings Institutions.

MoE (2015). Nepal Education in Figures, 2015: At a Glance. Kathmandu: Government of Nepal, Ministry of Education.

Nehru, V., Swanson, E., \& Dubey, A. (1995). A new database on human capital stock in developing and industrial countries: Sources, methodology, and results. Journal of Development Economics, 46(2), 379-401.

Nyasha, S., \& Odhiambo, N. M. (2015). The impact of banks and stock market development 
26 I PYC Nepal Journal of Management, August 2019, Vol. XII, No. 1

on economic growth in South Africa: An ARDL-bounds testing approach. Contemporary Economics, 9(1), 93-108.

Obstfeld, M. (1995). Risk taking, global diversification and growth. American Economic Review, 84(5), 1310-1329.

Pagano, M. (1993). Financial markets and growth: An overview. European Economic Review, 37(2-3), 613-622.

Petersen, M. A., \& Rajan, R. G. (1995). The effect of credit market competition on lending relationships. The Quarterly Journal of Economics, 110(2), 407-443.

Phillips, P. C. B., \& Perron, P. (1988). Testing for unit root in time series regression. Biometrika, 75(2), 335-346.

Rajan, R., \& Zingales, L. (1998). Financial dependence and growth. American Economic Review, 88(3), 559-586.

Rebelo, S. (1991). Long run policy analysis and long run growth. Journal of Political Economy, 99(3), 500-521.

Romer, P. M. (1986). Increasing returns and long run growth. Journal of Political Economy, 94(5), 1002-1037.

Wooldridge, J. M. (2009). Econometrics. New Delhi: Cenage Learning India. 